\title{
Genetic and restriction analysis of the 16S-23S rDNA internal transcribed spacer regions of the acetic acid bacteria
}

\author{
Journal Article \\ Author(s): \\ Trček, Janja; Teuber, Michael \\ Publication date: \\ 2002 \\ Permanent link: \\ https://doi.org/10.3929/ethz-b-000422664 \\ Rights / license: \\ In Copyright - Non-Commercial Use Permitted \\ Originally published in: \\ FEMS Microbiology 208(1), https://doi.org/10.1111/j.1574-6968.2002.tb11062.x
}




\title{
Genetic and restriction analysis of the $16 \mathrm{~S}-23 \mathrm{~S}$ rDNA internal transcribed spacer regions of the acetic acid bacteria
}

\author{
Janja Trček ${ }^{a, *}$, Michael Teuber ${ }^{b}$ \\ a Limnos, Podlimbarskega 31, SI-1000 Ljubljana, Slovenia \\ b Institute of Food Science and Technology, Laboratory of Food Microbiology, ETH-Zürich, CH-8092 Zürich, Switzerland
}

Received 21 September 2001; received in revised form 10 December 2001; accepted 13 December 2001

First published online 30 January 2002

\begin{abstract}
The 16S-23S rDNA internal transcribed spacer regions of the acetic acid bacteria were sequenced and evaluated for molecular identification of these bacteria. All the sequenced spacers contained genes for tRNA ${ }^{\text {Ile }}$ and $t R N A^{\text {Ala }}$, and the antitermination element. The sequences revealed 56.8-78.3\% similarity. By PCR amplification of the spacers from 57 strains of acetic acid bacteria, single products of similar sizes were produced. Digestion of the spacers by HaeIII and HpaII restriction enzymes resulted in 12 distinct groups of restriction types. All the restriction profiles obtained after analysis of microbial populations from vinegar matched one of the 12 groups. (C) 2002 Federation of European Microbiological Societies. Published by Elsevier Science B.V. All rights reserved.
\end{abstract}

Keywords: Acetic acid bacteria; Acetobacter; Gluconacetobacter; Gluconobacter; 16S-23S rDNA spacer; Vinegar

\section{Introduction}

Acetic acid bacteria are widespread microorganisms in nature. An ability to oxidize different kinds of sugars and a strict requirement for an aerobic atmosphere stimulate their growth on various plants (flowers, herbs, fruits etc.). Insects, especially bees, coming into contact with plants disseminate the acetic acid bacteria [1]. The ability to oxidize ethanol to acetic acid enables growth of the acetic acid bacteria in wine, cider, sake and kombucha tea, resulting in the production of different kinds of vinegar and beverages. Another characteristic of the acetic acid bacteria, widely used for the production of Nata de Coco, is the ability to produce considerable amounts of extracellular polysaccharides. Besides producing the desired food, the acetic acid bacteria can also spoil beer, juice, wine and fruits [1].

The taxonomy of the acetic acid bacteria has been substantially changed in recent years [2,3]. The acetic acid bacteria are at present classified into five genera: Acetobacter (A.), Gluconacetobacter (Ga.), Gluconobacter (G.), Acidomonas (Ac.) and Asaia (As.). The phenotypic identi-

* Corresponding author. Tel./Fax: +386 (1) 3651507.

E-mail address: janja.trcek@guest.arnes.si (J. Trček). fication of the acetic acid bacteria, especially at the level of species, is difficult [1]. One of the reasons for this difficulty is the high frequency of spontaneous mutations, attributed to the presence of insertion elements in the acetic acid bacteria [4]. Another reason might be structural changes in crucial enzymes, such as alcohol dehydrogenase, causing transformation of the enzyme from the active to the inactive form and vice versa [5].

Since the acetic acid bacteria are involved in the production or spoilage of food, their species identity is important information for the technologist trying to control a bioprocess in the food industry. The identification methods, based on analysis of the phenotypic characteristics of the acetic acid bacteria, are not only inaccurate, but also very time-consuming. Therefore, the application of molecular methods, based on the identification/characterization of specific DNA segments, could be a proper solution for the quick and accurate identification of these microorganisms.

We present, on a model of 57 reference strains and natural isolates, the applicability of restriction fragment length polymorphism of the $16 \mathrm{~S}-23 \mathrm{~S}$ rDNA spacer region for genus and species delineation of the acetic acid bacteria. With the aim of finding the optimal restriction enzymes, the 16S-23S rDNA spacer regions from some of the type strains of the genera Acetobacter, Gluconaceto- 
Table 1

Bacterial strains, source of isolation, accession numbers of the $16 \mathrm{~S}$ rDNA sequences and restriction types resulting from restriction analysis of the PCRamplified 16S-23S rDNA ITS regions

\begin{tabular}{|c|c|c|c|c|c|}
\hline \multirow[t]{2}{*}{ Species } & \multirow[t]{2}{*}{$\begin{array}{l}\text { Strain } \\
\text { designation }\end{array}$} & \multirow[t]{2}{*}{ Source of isolation } & \multirow[t]{2}{*}{$\begin{array}{l}\text { Identification based on } 16 \mathrm{~S} \text { rDNA sequence } \\
\text { (accession number in parentheses) }\end{array}$} & \multicolumn{2}{|c|}{$\begin{array}{l}\text { Restriction type } \\
\text { after restriction }\end{array}$} \\
\hline & & & & HaeIII & $H p$ \\
\hline \multicolumn{6}{|l|}{ Group $A$. aceti } \\
\hline A. aceti $^{\mathrm{T}}$ & DSM 3508 & $\begin{array}{l}\text { beech-wood shavings from a vinegar } \\
\text { plant }\end{array}$ & A. aceti $(\mathrm{X} 74066)^{\mathrm{a}}$ & $\mathrm{A}_{1}$ & $\mathrm{~B}_{1}$ \\
\hline A. aceti & LMG 1531 & n.k. & A. aceti (AJ130729) & $\mathrm{A}_{1}$ & $\mathrm{~B}_{2}$ \\
\hline A. aceti & LMG 1512 & film in fermenter of rice vinegar, Japan & A. aceti (AJ012545) & $\mathrm{A}_{2}$ & $\mathrm{~B}_{1}$ \\
\hline A. aceti & LMG 1496 & n.k. & A. aceti (AJ012541) & $\mathrm{A}_{1}$ & $\mathrm{~B}_{1}$ \\
\hline A. aceti & LMG 1525 & quick vinegar, The Netherlands & n.d. & $\mathrm{A}_{1}$ & $\mathrm{~B}_{1}$ \\
\hline A. aceti & LMG 1372 & $\begin{array}{l}\text { Nakano rice vinegar-producing } \\
\text { company }\end{array}$ & n.d. & $\mathrm{A}_{2}$ & $\mathrm{~B}_{1}$ \\
\hline A. aceti & ZIM B034, SegI/9 & $\begin{array}{l}\text { submerged culture alcohol vinegar } \\
\text { bioreactor, Slovenia }\end{array}$ & A. aceti (AJ130731) & $\mathrm{A}_{1}$ & $\mathrm{~B}_{1}$ \\
\hline A. aceti & ZIM B043, 105 & $\begin{array}{l}\text { submerged culture alcohol vinegar } \\
\text { bioreactor, Slovenia }\end{array}$ & A. aceti (AJ012542) & $\mathrm{A}_{1}$ & $\mathrm{~B}_{1}$ \\
\hline \multicolumn{6}{|c|}{ Group A. pasteurianus/A. pomorum } \\
\hline A. pasteurianus ${ }^{\mathrm{T}}$ & LMG 1262 & beer, The Netherlands & A. pasteurianus $(\mathrm{X} 71863)^{\mathrm{a}}$ & $\mathrm{P}_{1}$ & $\mathrm{R}$ \\
\hline A. pasteurianus & LMG 1543 & vinegar brews, Africa & A. pasteurianus (AJ130728) & $\mathrm{P}_{1}$ & $\mathrm{R}$ \\
\hline A. pasteurianus & LMG 1607 & n.k. & n.d. & $\mathrm{P}_{1}$ & $\mathrm{R}$ \\
\hline A. pasteurianus & LMG 1609 & n.k. & n.d. & $\mathrm{P}_{1}$ & $\mathrm{R}$ \\
\hline A. pasteurianus & ACM 2866 & n.k. & n.d. & $\mathrm{P}_{2}$ & $\mathrm{R}$ \\
\hline A. pomorum $^{\mathrm{T}}$ & LTH 2458 & cider vinegar, Germany & A. pomorum $(\mathrm{AJ} 001632)^{\mathrm{b}}$ & $\mathrm{P}_{1}$ & $\mathrm{R}$ \\
\hline \multicolumn{6}{|c|}{ Group Ga. europaeus/Ga. xylinus } \\
\hline Ga. europaeus ${ }^{\mathrm{T}}$ & DSM 6160 & $\begin{array}{l}\text { submerged culture vinegar bioreactor, } \\
\text { Germany }\end{array}$ & Ga. europaeus $(\mathrm{Z} 21936)^{\mathrm{a}}$ & $\mathrm{E}_{1}$ & $\mathrm{~F}_{1}$ \\
\hline Ga. europaeus & DSM 6161 & $\begin{array}{l}\text { submerged culture vinegar bioreactor, } \\
\text { Germany }\end{array}$ & Ga. europaeus ${ }^{\mathrm{c}}$ & $\mathrm{E}_{1}$ & $\mathrm{~F}_{1}$ \\
\hline Ga. europaeus & ZIM B059, S1 & $\begin{array}{l}\text { submerged culture vinegar bioreactor, } \\
\text { Germany }\end{array}$ & Ga. europaeus ${ }^{\mathrm{c}}$ & $\mathrm{E}_{2}$ & $\mathrm{~F}_{1}$ \\
\hline Ga. europaeus & ZIM B058, S3 & $\begin{array}{l}\text { submerged culture vinegar bioreactor, } \\
\text { Germany }\end{array}$ & n.d. & $\mathrm{E}_{1}$ & $\mathrm{~F}_{1}$ \\
\hline Ga. europaeus & SegI/4 & $\begin{array}{l}\text { submerged culture alcohol vinegar } \\
\text { bioreactor, Slovenia }\end{array}$ & Ga. europaeus (AJ130727) & $\mathrm{E}_{1}$ & $\mathrm{~F}_{1}$ \\
\hline Ga. europaeus & ZIM B053, TSA4 & $\begin{array}{l}\text { vinegar-producing generator, } \\
\text { Switzerland }\end{array}$ & Ga. europaeus ${ }^{\mathrm{c}}$ & $\mathrm{E}_{1}$ & $\mathrm{~F}_{1}$ \\
\hline Ga. europaeus & ZIM B028, V3 & $\begin{array}{l}\text { submerged culture red wine vinegar, } \\
\text { Slovenia }\end{array}$ & Ga. europaeus (AJ012698) ${ }^{\mathrm{d}}$ & $\mathrm{E}_{2}$ & $\mathrm{~F}_{2}$ \\
\hline Ga. europaeus & DSM 13109, JK2 & $\begin{array}{l}\text { submerged culture alcohol vinegar } \\
\text { bioreactor, Slovenia }\end{array}$ & Ga. europaeus $(\mathrm{Y} 15289)^{\mathrm{d}}$ & $\mathrm{E}_{2}$ & $\mathrm{~F}_{1}$ \\
\hline Ga. xylinus $^{\mathrm{T}}$ & LMG 1515 & mountain ash berries & Ga. xylinus $(\mathrm{X} 75619)^{\mathrm{a}}$ & $\mathrm{E}_{2}$ & $\mathrm{~F}_{3}$ \\
\hline Ga. xylinus & DSM 46604 & n.k. & Ga. europaeus (AJ316552) & $\mathrm{E}_{2}$ & $\mathrm{~F}_{1}$ \\
\hline Ga. xylinus & LMG 25 & n.k. & Ga. europaeus (AJ316551) & $\mathrm{E}_{2}$ & $\mathrm{~F}_{4}$ \\
\hline Ga. xylinus & DSM 46603 & n.k. & n.d. & $\mathrm{E}_{2}$ & $\mathrm{~F}_{1}$ \\
\hline Ga. xylinus & DSM 2004 & vinegar brew, Kenya & n.d. & $\mathrm{E}_{2}$ & $\mathrm{~F}_{1}$ \\
\hline Ga. xylinus & DSM 2325 & n.k. & n.d. & $\mathrm{E}_{2}$ & $\mathrm{~F}_{3}$ \\
\hline \multicolumn{6}{|c|}{ Group Ga. intermedius/Ga. oboediens } \\
\hline Ga. intermedius ${ }^{\mathrm{T}}$ & DSM 11804 & kombucha beverage, Switzerland & Ga. intermedius (Y14694) ${ }^{\mathrm{c}}$ & $\mathrm{I}_{1}$ & $\mathrm{~J}_{1}$ \\
\hline Ga. intermedius & DSM 13111, JK3 & $\begin{array}{l}\text { submerged culture cider vinegar, } \\
\text { Slovenia }\end{array}$ & Ga. intermedius $(\mathrm{AJ} 012699)^{\mathrm{d}}$ & $\mathrm{I}_{1}$ & $\mathbf{J}_{2}$ \\
\hline Ga. intermedius & ZIM B051, TSN3 & $\begin{array}{l}\text { vinegar-producing generator, } \\
\text { Switzerland }\end{array}$ & Ga. intermedius ${ }^{\mathrm{c}}$ & $\mathrm{I}_{1}$ & $\mathrm{~J}_{2}$ \\
\hline Ga. intermedius & ZIM B074, E1 & $\begin{array}{l}\text { submerged culture vinegar bioreactor, } \\
\text { Spain }\end{array}$ & Ga. intermedius ${ }^{\mathrm{c}}$ & $\mathrm{I}_{1}$ & $J_{1}$ \\
\hline Ga. intermedius & $\begin{array}{l}\text { ZIM B062, } \\
\text { ØSSPR }\end{array}$ & $\begin{array}{l}\text { submerged culture vinegar bioreactor, } \\
\text { Switzerland }\end{array}$ & Ga. intermedius ${ }^{\mathrm{c}}$ & $\mathrm{I}_{1}$ & $\mathbf{J}_{2}$ \\
\hline Ga. hansenii & LMG 1517 & n.k. & Ga. intermedius (AJ012464) & $\mathrm{I}_{1}$ & $\mathbf{J}_{3}$ \\
\hline Ga. hansenii & LMG 1689 & n.k. & Ga. intermedius (AJ316550) & $\mathrm{I}_{1}$ & $\mathbf{J}_{3}$ \\
\hline Ga. xylinus & LMG 1510 & vinegar, Denmark & Ga. intermedius (AJ316549) & $\mathrm{I}_{1}$ & $\mathbf{J}_{1}$ \\
\hline Ga. oboediens ${ }^{\mathrm{T}}$ & LTH 2460 & red wine vinegar, Germany & Ga. oboediens $(\mathrm{AJ} 001631)^{\mathrm{b}}$ & $\mathrm{I}_{1}$ & $\mathbf{J}_{2}$ \\
\hline \multicolumn{6}{|c|}{ Group Ga. hansenii } \\
\hline Ga. hansenii ${ }^{\mathrm{T}}$ & LMG 1527 & vinegar, Jerusalem & Ga. hansenii $(\mathrm{X} 75620)^{\mathrm{a}}$ & $\mathrm{H}_{1}$ & \\
\hline
\end{tabular}


Table 1 (continued)

\begin{tabular}{|c|c|c|c|c|c|}
\hline \multirow[t]{2}{*}{ Species } & \multirow[t]{2}{*}{$\begin{array}{l}\text { Strain } \\
\text { designation }\end{array}$} & \multirow[t]{2}{*}{ Source of isolation } & \multirow[t]{2}{*}{$\begin{array}{l}\text { Identification based on } 16 \mathrm{~S} \text { rDNA sequence } \\
\text { (accession number in parentheses) }\end{array}$} & \multicolumn{2}{|c|}{$\begin{array}{l}\text { Restriction types obtained } \\
\text { after restriction with: }\end{array}$} \\
\hline & & & & HaeIII & HpaII \\
\hline Ga. hansenii & LMG 1524 & vinegar, Jerusalem & Ga. hansenii (AJ012543) & $\mathrm{H}_{1}$ & $\mathrm{~K}_{1}$ \\
\hline Ga. hansenii & LMG 1529 & malt vinegar brewery acetifier & Ga. hansenii (AJ012544) & $\mathrm{H}_{2}$ & $\mathrm{~K}_{2}$ \\
\hline Ga. hansenii & ZIM B033, SegI/2 & $\begin{array}{l}2 \text { submerged culture alcohol vinegar } \\
\text { bioreactor, Slovenia }\end{array}$ & Ga. hansenii (AJ130732) & $\mathrm{H}_{1}$ & $\mathrm{~K}_{1}$ \\
\hline Ga. hansenii & $\begin{array}{l}\text { ZIM B040, SegII/ } \\
12\end{array}$ & $\begin{array}{l}\text { submerged culture alcohol vinegar } \\
\text { bioreactor, Slovenia }\end{array}$ & Ga. hansenii (AJ130726) & $\mathrm{H}_{1}$ & $\mathrm{~K}_{1}$ \\
\hline Ga. hansenii & $\begin{array}{l}\text { ZIM B041, SegII/ } \\
14\end{array}$ & $\begin{array}{l}\text { submerged culture alcohol vinegar } \\
\text { bioreactor, Slovenia }\end{array}$ & Ga. hansenii (AJ130730) & $\mathrm{H}_{1}$ & $\mathrm{~K}_{1}$ \\
\hline \multicolumn{6}{|c|}{ Group Ga. liquefaciens } \\
\hline Ga. liquefaciens ${ }^{\mathrm{T}}$ & LMG 1382 & dried fruit, Japan & Ga. liquefaciens $(\mathrm{X} 75617)^{\mathrm{a}}$ & $\mathrm{L}_{1}$ & $\mathrm{Q}_{1}$ \\
\hline Ga. liquefaciens & SRI 244 & sugar cane, Australia & Ga. liquefaciens $(\mathrm{AF} 127391)^{\mathrm{e}}$ & $\mathrm{L}_{2}$ & $\mathrm{Q}_{2}$ \\
\hline Ga. liquefaciens & SRI 1994 & mealy bug, Australia & Ga. liquefaciens $(\mathrm{AF} 127395)^{\mathrm{e}}$ & $\mathrm{L}_{2}$ & $\mathrm{Q}_{2}$ \\
\hline \multicolumn{6}{|c|}{ Group Ga. diazotrophicus } \\
\hline $\begin{array}{l}\text { Ga. diazotrophicus }{ }^{\mathrm{T}} \\
\text { Group Ga. sacchart }\end{array}$ & LMG 7603 & Saccharum officinarum, Hawaii & Ga. diazotrophicus $(75618)^{\mathrm{a}}$ & $\mathrm{D}_{1}$ & $\mathrm{C}_{1}$ \\
\hline Ga. sacchari ${ }^{\mathrm{T}}$ & SRI 1794 & sugar cane, Australia & Ga. sacchari $(\mathrm{AF} 127407)^{\mathrm{e}}$ & $\mathrm{S}_{1}$ & $\mathrm{~V}_{1}$ \\
\hline \multicolumn{6}{|c|}{ Group Ac. methanolica } \\
\hline $\begin{array}{l}\text { Ac. methanolica } \\
\text { Group G. oxydans }\end{array}$ & LMG 1668 & ethanol fermentation process, Germany & Ac. methanolica $(\mathrm{X} 77468)^{\mathrm{a}}$ & $\mathrm{M}_{1}$ & $\mathrm{~B}_{1}$ \\
\hline G. oxydans ${ }^{\mathrm{T}}$ & DSM 3503 & beer & G. oxydans $(\mathrm{X} 73820)^{\mathrm{a}}$ & $\mathrm{G}_{1}$ & $\mathrm{O}_{1}$ \\
\hline G. oxydans & DSM 3504 & n.k. & n.d. & $\mathrm{G}_{1}$ & $\mathrm{O}_{1}$ \\
\hline G. oxydans & DSM 50049 & Amstel beer, The Netherlands & n.d. & $\mathrm{G}_{1}$ & $\mathrm{O}_{1}$ \\
\hline G. oxydans & DSM 46616 & n.k. & n.d. & $\mathrm{G}_{1}$ & $\mathrm{O}_{1}$ \\
\hline $\begin{array}{l}\text { G. oxydans } \\
\text { Group G. asaii }\end{array}$ & CECT 4009 & n.k. & n.d. & $\mathrm{G}_{1}$ & $\mathrm{O}_{1}$ \\
\hline G. asaii ${ }^{\mathrm{T}}$ & LMG 1390 & Rheum rhabarbarum, flower, Japan & G. asaii $(\mathrm{X} 80165)^{\mathrm{a}}$ & $\mathrm{G}_{2}$ & $\mathrm{~T}_{1}$ \\
\hline Group $G$. cerinus/G & J. frateurii & & & & \\
\hline G. cerinus $^{\mathrm{T}}$ & LMG 1368 t2 & cherry, Japan & G. cerinus $(\mathrm{X} 80775)^{\mathrm{a}}$ & $\mathrm{G}_{2}$ & $\mathrm{U}_{1}$ \\
\hline G. frateurii $^{\mathrm{T}}$ & DSM 7146 & Fragaria ananassa, Japan & G. frateurii $(\mathrm{X} 82290)^{\mathrm{a}}$ & $\mathrm{G}_{2}$ & $\mathrm{U}_{1}$ \\
\hline
\end{tabular}

Superscript T, type strain; n.k., not known; n.d., not determined; SRI, Sugar Research Institute, Mackay, Australia; LMG, Laboratorium voor Microbiologie, Gent, Belgium; for the abbreviations DSM, ZIM, CECT, LTH and ACM see Section 2.

${ }^{\mathrm{a}}$ Data taken from Sievers et al. [9].

${ }^{b}$ Data taken from Sokollek et al. [24].

${ }^{\mathrm{c}}$ Data taken from Boesch et al. [7].

${ }^{\mathrm{d}}$ Data taken from Trček et al. [25].

${ }^{\mathrm{e}}$ Data taken from Franke et al. [26].

bacter and Gluconobacter were initially sequenced and the sequences analyzed in more detail.

\section{Materials and methods}

\subsection{Microorganisms}

All microorganisms used in this study are listed in Table 1. They were purchased from the German Collection of Microorganisms and Cell Cultures (DSM), the Belgian Coordinated Collections of Microorganisms (BCCM), the Slovene Collection of Industrial Microorganisms (ZIM), the Spanish Type Culture Collection (CECT), the Institute for Food Science and Technology, University of Hohenheim (LTH) and the Australian Collection of Microorganisms (ACM). They were maintained as described in the catalogues of the culture collections.

\subsection{DNA isolation}

DNA was isolated as described previously [6] or by temperature lysis of cells (cooking at $95^{\circ} \mathrm{C}$ for $10 \mathrm{~min}$ and subsequent cooling to $4^{\circ} \mathrm{C}$ ).

\subsection{Amplification of the $16 S-23 S$ rDNA and restriction analysis}

PCR of the 16S-23S rDNA spacer regions was performed in $100 \mu 1$ solution containing 15-20 ng of DNA, $0.2 \mathrm{mM}$ each of dATP, dCTP, dGTP and dTTP, $10 \mu \mathrm{l}$ $10 \times$ standard PCR buffer (Pharmacia Biotech), sterile double-distilled water, 100 pmol of each primer and 2.5 U Taq DNA polymerase (Pharmacia Biotech). The sequences of the primers were $5^{\prime}$-TGCGG(C/T)TGGATCACCTCCT-3' (position 1522-1540 on 16S rDNA, Escherichia coli numbering) and 5'-GTGCC(A/T)AGGC- 
Table 2

Sequencing primers for the $16 \mathrm{~S}-23 \mathrm{~S}$ rDNA spacer region

\begin{tabular}{|c|c|c|c|}
\hline Primer & Sequence & Target site & Reference \\
\hline Uni1392 & 5'-GTACACACCGCCCGTCA-3' & 16S rDNA, $1392-1408^{a}$ & {$[27]$} \\
\hline b-1 & 5'-ATACGGGGCTATCACCCG-3' & $23 \mathrm{~S}$ rDNA, $340-323^{\mathrm{a}}$ & {$[27]$} \\
\hline TAlaf & 5'-AGAGCACCTGCTTTGCAA-3' & $16 \mathrm{~S}-23 \mathrm{~S}$ rDNA, $285-300^{\mathrm{b}}$ & This study \\
\hline TAlar & 5'-ACССССТGCTTGCAAA-3' & $16 \mathrm{~S}-23 \mathrm{~S}$ rDNA, 311-296 ${ }^{\mathrm{b}}$ & This study \\
\hline
\end{tabular}

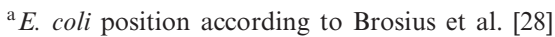

${ }^{\mathrm{b}} \mathrm{Ga}$. hansenii position (accession number AJ007832)

ATCCACCG-3' (position 38-22 on 23S rDNA, E. coli numbering). PCR products used for the sequencing analysis were obtained by the following primers: 5'CGTGTCGTGAGATGTTGG-3' (position 1071-1087 on 16S rDNA, E. coli numbering) and 5'-CGGGGTGCTTTTCACCTTTCC-3' (position $488-468$ on $23 \mathrm{~S}$ rDNA, E. coli numbering). The synthesized oligonucleotide primers were obtained from Microsynth (Balgach, Switzerland). Amplification was performed in 0.2-ml tubes using Genius thermocycler (Genius, Techne). The cycling program started with initial denaturation of DNA at $94^{\circ} \mathrm{C}$ for $5 \mathrm{~min}$ and continued with 30 cycles of $92^{\circ} \mathrm{C}$ for $30 \mathrm{~s}$, $56^{\circ} \mathrm{C}$ for $45 \mathrm{~s}$ and $72^{\circ} \mathrm{C}$ for $1 \mathrm{~min}$. The polymerization time was increased to $2 \mathrm{~min}$ when primers for the amplification of the rDNA fragment for direct sequencing were used. At the end a final extension at $72^{\circ} \mathrm{C}$ for 7 min was performed, followed by cooling down to $4^{\circ} \mathrm{C}$. PCR products were electrophoresed in $1.0 \% \mathrm{w} / \mathrm{v}$ agarose gels submerged in $1 \times$ Tris-acetate running buffer. The $1-\mathrm{kb}$ plus DNA ladder (Life Technologies) was used as a length standard.

PCR products were digested separately with HaeIII and HpaII restriction enzymes following the instructions of the manufacturer (Life Technologies). Restriction fragments were analyzed by $2.5 \% \mathrm{w} / \mathrm{v}$ agarose gel electrophoresis in $1 \times$ Tris-acetate running buffer. The length of the restriction fragments was calculated relative to that of DNA marker by linear regression of the semilogarithmic curve (mobility vs. logarithm of DNA fragment length).

\subsection{Amplification and sequencing of the $16 \mathrm{~S}$ rDNA}

The genes encoding 16S rRNA were amplified in vitro using oligonucleotide primers 5'-AAATTGAAGAGTTTGATC(A/C)TGGC-3' (position 1-23 on 16S rDNA, E. coli numbering) and $5^{\prime}$-AGGAGGTGATCC(A/G)CCGCA-3' (position 1540-1522 on 16S rDNA, E. coli numbering). PCR was performed as described above for the amplification of the 16S-23S spacer regions using an appropriate polymerization time $(1.5 \mathrm{~min})$ for this set of primers. Direct sequencing of the PCR products was performed as described below for the sequencing of the $16 \mathrm{~S}$ 23S spacer regions using the primers described by Boesch et al. [7].

\subsection{Sequencing of the $16 S-23 S$ rDNA spacer regions}

Direct sequencing of the purified PCR products was performed by the Thermo Sequenase fluorescent labeled primer cycle sequencing kit with 7-deaza-dGTP according to the manufacturer's instructions (Amersham). The Cy5labeled sequencing primers (Table 2) were obtained from Microsynth (Balgach, Switzerland). Cycle sequencing was performed on a Biometra Personal Cycler (Biometra, Göttingen, Germany) during 25 cycles of the following parameters: $95^{\circ} \mathrm{C}$ for $30 \mathrm{~s}, 50^{\circ} \mathrm{C}$ for $30 \mathrm{~s}$ and $72^{\circ} \mathrm{C}$ for $1 \mathrm{~min}$. Detection was performed on an ALF-Express automatic DNA sequencer (Pharmacia Biotech).

\subsection{Nucleotide sequence deposition numbers}

All the nucleotide sequences were deposited in the EMBL/GenBank/DDBJ databases. Nucleotide sequences of the 16S-23S rDNA spacer region of $A$. $\operatorname{aceti}^{\mathrm{T}}, A$. pasteurianus $^{\mathrm{T}}$, Ga. hansenii ${ }^{\mathrm{T}}$, Ga. liquefaciens $^{\mathrm{T}}$, and $\mathrm{G}$. oxydans $^{\mathrm{T}}$ were deposited under the accession numbers AJ007831, AJ007834, AJ007832, AJ007833, and AJ007763, respectively. The accession numbers of the 16S rRNA gene sequences are listed in Table 1.

\section{Results and discussion}

\subsection{Sequence comparison of the $16 S-23 S$ rDNA spacers}

Using primers constructed from the conserved regions of the genes encoding $16 \mathrm{~S}$ and $23 \mathrm{~S}$ rRNA, the 16S-23S

Table 3

Percentage of nucleotide similarity among the acetic acid bacteria based on 16S-23S rDNA ITS regions

\begin{tabular}{lllllll}
\hline Species & \multicolumn{7}{l}{ Sequence similarity $(\%)$} \\
\cline { 2 - 7 } & 1 & 2 & 3 & 4 & 5 & 6 \\
\hline 1. A. aceti & 67.8 & & & & & \\
2. A. pasteurianus & 64.1 & 67.3 & & & & \\
3. Ga. europaeus & 56.8 & 69.7 & 69.4 & & & \\
4. Ga. hansenii & 69.3 & 65.6 & 60.0 & 61.4 & & \\
5. Ga. liquefaciens & 59.6 & 64.5 & 78.3 & 64.1 & 58.7 & \\
6. Ga. xylinus & 62.7 & 59.2 & 61.4 & 61.6 & 62.6 & 56.8 \\
7. G. oxydans & & & & & & \\
\hline
\end{tabular}




\begin{tabular}{|c|c|}
\hline E. coli & $\mathrm{T}$ G C $\mathbf{T} \mathbf{C}$ T $\mathbf{T}$ T A A C A \\
\hline A. aceti & 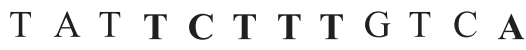 \\
\hline A. pasteurianus & $\mathrm{T}$ G A $\mathbf{T} \mathbf{C} \mathbf{T} \mathbf{T} \mathbf{T} G \mathrm{~T}$ C \\
\hline Ga. europaeus & $\mathrm{T}$ G C $\mathbf{T} \mathbf{C} \mathbf{T} \mathbf{T}$ \\
\hline Ga. hansenii & $\mathrm{T} \quad \mathrm{G} \quad \mathrm{T} \quad \mathbf{T} \quad \mathbf{C} \quad \mathbf{T} \quad \mathbf{T} \quad \mathbf{T} G \quad \mathrm{G} \quad \mathrm{C}$ \\
\hline Ga. liquefaciens & 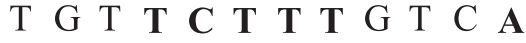 \\
\hline Ga.xylinus & 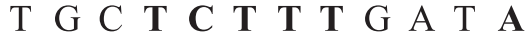 \\
\hline G. oxydans & G G G T \\
\hline
\end{tabular}

Fig. 1. Alignment between the box A-like sequences from the $16 \mathrm{~S}-23 \mathrm{~S}$ rDNA regions of E. coli [12], A. aceti ${ }^{\mathrm{T}}, A$. pasteurianus $^{\mathrm{T}}, G a$. europaeus $^{\mathrm{T}}$, Ga. hansenii $^{\mathrm{T}}$, Ga. liquefaciens $^{\mathrm{T}}, G a{\text {. } \text { xylinus }^{\mathrm{T}} \text { and } G \text {. oxydans }}^{\mathrm{T}}$.

rDNA spacers of the type strains of $A$. aceti, A. pasteurianus, Ga. hansenii, Ga. liquefaciens and $G$. oxydans were specifically amplified. By direct sequencing of the PCR products, 724, 724, 725, 704, and 653 bp long spacers were determined for A. aceti, A. pasteurianus, Ga. hansenii, Ga. liquefaciens and $G$. oxydans, respectively. Alignment of these sequences and the sequences from type strains of $G a$. europaeus and Ga. xylinus [8] exhibits 56.8-78.3\% similarity (Table 3 ). The much lower similarities of these sequences in comparison with the $94.2-99.6 \%$ similarities of the $16 \mathrm{~S}$ rDNA sequences [9] are a result of greater evolutionary rates in the rDNA spacers [10]. On the other hand, two highly conserved regions (96-100\% similarity), encoding tRNA ${ }^{\text {Ile }}(77 \mathrm{bp})$ and $\mathrm{tRNA}^{\text {Ala }}(75 \mathrm{bp})$, were found in the spacers of all acetic acid bacteria. These sequences are believed to have an important role in the process of rRNA formation [11]. The $3^{\prime}$-end terminal sequence CCA normally present in mature tRNA was observed in both tRNAs. The antitermination elements, box A-like sequences (Fig. 1), have two to four mismatches with the corresponding sequence of E. coli [12]. Another highly conserved region of 17 nucleotides, following the box A element, has been found in the spacers of all acetic acid bacteria (data not shown).

The sequences of the $16 \mathrm{~S}$ rRNA of the acetic acid bacteria are very similar to each other [3]. This causes problems in delineating all the species of the acetic acid bacteria on the basis of restriction fragment length polymorphism of the $16 \mathrm{~S}$ rDNA [13]. Much higher variability in sequence composition of the spacer regions prompted us to test the applicability of the restriction fragment length polymorphism of the PCR-amplified spacer region for easy and quick species differentiation of the acetic acid bacteria. This approach was already successfully used for the strain classification and identification of many bacteria. Recently, also a database for 16S-23S rDNA sequences was established (http:// ulises.umh.es/RISSC) enabling comparison of these sequences from different bacteria [14]. To be able to evaluate the above-mentioned approach for species identification of the acetic acid bacteria, exact species identity is obligatory information. Therefore, the species identity of the acetic acid bacteria was checked by sequencing of the genes encoding $16 \mathrm{~S}$ rRNA.

\subsection{Sequence analysis of the genes encoding $16 S r R N A$}

For most of the strains described in Table 1, the 16S rDNA sequences were entirely or partially determined and aligned with previously described $16 \mathrm{~S}$ rDNA sequences of the acetic acid bacteria. The strain was classified into the species with which its $16 \mathrm{~S}$ rDNA sequence exhibited the highest percentage of similarity. All the sequences were deposited into the EMBL/GenBank/DDBJ databases; the accession numbers are listed in Table 1.

Gosselé et al. [15] have reclassified strains $A$. acet $i$ subsp. xylinus LMG 1517 (NCIM 4940) and $A$. aceti subsp. xylinus LMG 1689 (LMD 29.8) into Ga. hansenii on the basis of their phenotypic features and protein gel electrophoregrams. Our results of partial sequencing of genes encoding $16 \mathrm{~S}$ rRNA could not place these strains into Ga. hansenii, nor strain Ga. xylinus LMG 1510 into species Ga. xylinus (Table 1). 16S rDNA sequences from Ga. hansenii LMG 1517, Ga. hansenii LMG 1689 and Ga. xylinus LMG 1510 matched best with the 16S rDNA sequence of $G a$. intermedius. For all three strains additional arguments exist suggesting their misclassification. Strains Ga. hansenii LMG 1517 and Ga. hansenii LMG 1689 showed very low DNA-DNA similarity ( $8 \%$ and $14 \%$ ) with $\mathrm{Ga}$. hansenii type strains as described by Navarro et al. [16]. For strain Ga. xylinus LMG 1510, Boesch [17] has shown below 15\% DNA-DNA similarity with the type strains of $G a$. xylinus and $G a$. europaeus.

\subsection{Size comparison of the $16 S-23 S$ rDNA spacer regions}

Small length polymorphism exists among the PCR-amplified spacers of the acetic acid bacteria, but the differences are difficult to recognize accurately and reliably by standard agarose gel electrophoresis. However, precise length evaluation of the PCR products shows that the products from the genus Gluconobacter are smaller than those from the other examined acetic acid bacteria (data not shown). Also the nucleotide sequence of the spacer from $G$. oxydans type strain is about $50 \mathrm{bp}$ smaller in comparison to the spacers from other analyzed acetic acid bacteria.

Sievers et al. [8] have estimated that four copies of the $16 \mathrm{~S}-23 \mathrm{~S}$ spacer region are present on the chromosome of $G a$. xylinus and $G a$. europaeus. In this study the copy number of the spacer regions was not studied. However, the single amplified PCR product of all 57 analyzed acetic acid bacteria suggests no length polymorphism among copies of the $16 \mathrm{~S}-23 \mathrm{~S}$ spacer region.

\subsection{Restriction analysis of the $16 S-23 S$ rDNA spacer regions}

Fifty-seven strains of acetic acid bacteria, which were obtained from different culture collections, were analyzed. In Table 1 strains are grouped according to their species 
identity recognized by sequencing of the gene for $16 \mathrm{~S}$ rRNA.

The sequences of $16 \mathrm{~S}-23 \mathrm{~S}$ ITS regions of the acetic acid bacteria were subjected to theoretical restriction analysis using the WebCutter program. Two enzymes, producing two to three restriction products and giving different restriction profiles among all species of the acetic acid bacteria, were selected and applied for restriction analysis of the reference strains. To avoid ambiguities due to the poor visibility and resolution limitations of the standard agarose gel electrophoresis, only fragments bigger than $100 \mathrm{bp}$ were taken into account for the interpretation of restriction patterns. The same letter and number were given to the same type of restriction patterns. For each strain, the patterns obtained with both enzymes were combined, resulting in the following 12 different restriction groups: $A$. aceti, A. pasteurianus/A. pomorum, Ga. europaeus/Ga. xylinus, Ga. intermedius/Ga. oboediens, Ga. hansenii, Ga. liquefaciens, Ga. diazotrophicus, Ga. sacchari, Ac. methanolica, G. oxydans, G. asaii, G. cerinus/G. frateurii. Each group exhibits up to four different HaeIII and HpaII restriction types (Tables 1, 4 and 5). None of the restriction profile from one restriction group was observed in the other restriction group, and more of the same restriction profiles were generated in the same restriction group. The only exception is profile $\mathrm{B}_{1}$, which is actually a result of no restriction site in the spacers of $A$. aceti and Ac. methanolica.

To prove that the presented collection of the restriction profiles might be used as a database to which the restriction profile of an unknown isolate from vinegar might be compared, strains were isolated from industrially produced wine vinegar. Six of them were randomly chosen for PCR amplification of spacer regions and subsequent restriction analysis. Comparison of their restriction profiles to the restriction profiles of the reference strains

Table 4

Molecular sizes of $16 \mathrm{~S}-23 \mathrm{~S}$ rDNA restriction fragments of different restriction types obtained with HaeIII

\begin{tabular}{ll}
\hline Restriction type & $\begin{array}{l}\text { Molecular size }(b p) \text { of } 16 S-23 S \text { rDNA } \\
\text { restriction fragments }\end{array}$ \\
\hline$A_{1}$ & 500,290 \\
$A_{2}$ & $310,290,190$ \\
$P_{1}$ & 470,300 \\
$P_{2}$ & $300,280,180$ \\
$E_{1}$ & $330,250,210$ \\
$E_{2}$ & 540,250 \\
$I_{1}$ & 510,260 \\
$H_{1}$ & $400,200,100$ \\
$H_{2}$ & $370,240,100$ \\
$L_{1}$ & 490,250 \\
$L_{2}$ & 430,250 \\
$D_{1}$ & $310,210,150$ \\
$S_{1}$ & 500,210 \\
$M_{1}$ & $260,230,190$ \\
$G_{1}$ & 520,120 \\
$G_{2}$ & 520,230 \\
\hline
\end{tabular}

Table 5

Molecular sizes of $16 \mathrm{~S}-23 \mathrm{~S}$ rDNA restriction fragments of different restriction types obtained with HpaII

\begin{tabular}{ll}
\hline Restriction type & $\begin{array}{l}\text { Molecular size }(\mathrm{bp}) \text { of } 16 \mathrm{~S}-23 \mathrm{~S} \text { rDNA } \\
\text { restriction fragments }\end{array}$ \\
\hline $\mathrm{B}_{1}$ & 800 \\
$\mathrm{~B}_{2}$ & 500,210 \\
$\mathrm{R}_{1}$ & 450,330 \\
$\mathrm{R}_{2}$ & $380,330,110$ \\
$\mathrm{R}_{3}$ & 560,210 \\
$\mathrm{~F}_{1}$ & $450,270,100$ \\
$\mathrm{~F}_{2}$ & $400,270,100$ \\
$\mathrm{~F}_{3}$ & 390 \\
$\mathrm{~F}_{4}$ & 470,140 \\
$\mathrm{~J}_{1}$ & $420,150,100$ \\
$\mathrm{~J}_{2}$ & $370,270,100$ \\
$\mathrm{~J}_{3}$ & $420,270,100$ \\
$\mathrm{~K}_{1}$ & $350,170,100$ \\
$\mathrm{~K}_{2}$ & $330,170,100$ \\
$\mathrm{Q}_{1}$ & 550,120 \\
$\mathrm{Q}_{2}$ & $430,160,120$ \\
$\mathrm{C}_{1}$ & 400,170 \\
$\mathrm{~V}_{1}$ & 380,210 \\
$\mathrm{O}_{1}$ & $340,220,160$ \\
$\mathrm{~T}_{1}$ & $480,160,100$ \\
$\mathrm{U}_{1}$ & 570,160 \\
\hline & \\
&
\end{tabular}

placed all isolates (restriction type $\mathrm{E}_{2} \mathrm{~F}_{1}$ ) in the group $G a$. europaeus/Ga. xylinus. The same result was obtained when total DNA isolated directly from biomass harvested from alcohol vinegar was used as a template in the PCR reaction.

Besides other characteristics, each genus of the acetic acid bacteria typically possesses a distinctive feature, which can be easily used for identification on the genus level. The genus Gluconobacter is characterized by inability to overoxidize acetic acid to $\mathrm{CO}_{2}$ and $\mathrm{H}_{2} \mathrm{O}$ [1]. The genus Acidomonas is characterized by its ability to grow on methanol [1] and the genus Asaia by its inability to grow on a $0.35 \%$ acetic acid-containing medium [3]. The two other genera, Acetobacter and Gluconacetobacter, can be differentiated from each other on the basis of ubiquinone Q-9 and ubiquinone Q-10 contents [2]. Further identification of the acetic acid bacteria at the species level is very time-consuming and cumbersome $[18,19]$. From our experiences almost each strain of the acetic acid bacteria has a unique growth requirement. That induces problems in using an appropriate minimal medium which is a prerequisite for further biochemical identification of isolates. In this study, a molecular approach has been studied with the aim to make a database of $16 \mathrm{~S}-23 \mathrm{~S}$ rDNA restriction profiles of the acetic acid bacteria. By comparing the restriction profile of an unknown isolate of an acetic acid bacterium with the restriction profiles presented here, the isolate can be quickly and simply assigned to one of 12 presented groups. The approach presented here was successfully used for identification of the acetic acid bacteria from vinegar. 


\section{Note added in proof}

During the preparation of this manuscript new species of the acetic acid bacteria were described [20-23].

\section{Acknowledgements}

This work was supported by the Ministry of Education, Science and Sport of the Republic of Slovenia (Project J42263-1509-00 and Grant S38-490-007/14279/97), the Kolinska Food Company and the Laboratory of Food Microbiology, ETH-Zürich. The authors would like to thank Prof. Dr. Peter Raspor (University of Ljubljana, Biotechnical Faculty, Food Science and Technology Department) for encouraging work on the acetic acid bacteria.

\section{References}

[1] Swings, J. (1992) The genera Acetobacter and Gluconobacter. In: The Prokaryotes. A Handbook on the Biology of Bacteria: Ecophysiology, Isolation, Identification, Applications, Vol. III (Balows, A., Trüper, H.G., Dworkin, M., Harder, W. and Schleifer, K.-H., Eds.), pp. 2268-2286. Springer-Verlag, New York.

[2] Yamada, Y., Hoshino, K. and Ishikawa, T. (1997) The phylogeny of acetic acid bacteria based on the partial sequences of $16 \mathrm{~S}$ ribosomal RNA: the elevation of the subgenus Gluconoacetobacter to the generic level. Biosci. Biotechnol. Biochem. 61, 1244-1251.

[3] Yamada, Y., Katsura, K., Kawasaki, H., Widyastuti, Y., Saono, S., Seki, T., Uchimura, T. and Komagata, K. (2000) Asaia bogorensis gen. nov., sp. nov., an unusual acetic acid bacterium in the $\alpha$-Proteobacteria. Int. J. Syst. Evol. Microbiol. 50, 823-829.

[4] Takemura, H., Horinouchi, S. and Beppu, T. (1991) Novel insertion sequence IS1380 from Acetobacter pasteurianus is involved in loss of ethanol-oxidizing ability. J. Bacteriol. 173, 7070-7076.

[5] Matsushita, K., Yakushi, T., Takaki, Y., Toyama, H. and Adachi, O. (1995) Generation mechanism and purification of an inactive form convertible in vivo to the active form of quinoprotein alcohol dehydrogenase in Gluconobacter suboxydans. J. Bacteriol. 177, 6552-6559.

[6] Trček, J., Ramuš, J. and Raspor, P. (1997) Phenotypic characterization and RAPD-PCR profiling of Acetobacter sp. isolated from spirit vinegar production. Food Technol. Biotechnol. 35, 63-67.

[7] Boesch, C., Trček, J., Sievers, M. and Teuber, M. (1998) Acetobacter intermedius, sp. nov.. Syst. Appl. Microbiol. 21, 220-229.

[8] Sievers, M., Alonso, L., Gianotti, S., Boesch, C. and Teuber, M. (1996) 16S-23S ribosomal RNA spacer regions of Acetobacter europaeus and $A$. xylinum, tRNA genes and antitermination sequences. FEMS Microbiol. Lett. 142, 43-48.

[9] Sievers, M., Ludwig, W. and Teuber, M. (1994) Phylogenetic position of Acetobacter, Gluconobacter, Rhodopila and Acidiphilium species as a branch of acidophilic bacteria in the $\alpha$-subclass of Proteobacteria based on 16S ribosomal DNA sequences. Syst. Appl. Microbiol. 17, 189-196.

[10] Barry, T., Colleran, G., Glennon, M., Dunican, L. and Gannon, F. (1991) The $16 \mathrm{~S} / 23 \mathrm{~S}$ ribosomal spacer region as a target for DNA probes to identify eubacteria. PCR Methods Appl. 1, 51-56.

[11] Srivastava, A.K. and Schlessinger, D. (1990) Mechanism and regulation of bacterial ribosomal RNA processing. Annu. Rev. Microbiol. 44, 105-129.

[12] Li, S.C., Squires, C.L. and Squires, C. (1984) Antitermination of $E$. coli rRNA transcription is caused by a control region segment containing lambda nut-like sequences. Cell 38, 851-860.
[13] Poblet, M., Rozès, N., Guillamón, J.M. and Mas, A. (2000) Identification of acetic acid bacteria by restriction fragment length polymorphism analysis of a PCR-amplified fragment of the gene coding for 16S rRNA. Lett. Appl. Microbiol. 31, 63-67.

[14] Garcia-Martinez, J., Bescos, I., Rodriguez-Sala, J.J. and RodriguezValera, F. (2001) RISSC: a novel database for ribosomal 16S-23S RNA genes spacer regions. Nucleic Acids Res. 29, 178-180.

[15] Gosselé, F., Swings, J., Kersters, K., Pauwels, P. and De Ley, J. (1983) Numerical analysis of phenotypic features and protein gel electrophoregrams of a wide variety of Acetobacter strains. Proposal for the improvement of the taxonomy of the genus Acetobacter Beijerinck 1898, 215. Syst. Appl. Microbiol. 4, 338-368.

[16] Navarro, R.R., Uchimura, T. and Komagata, K. (1999) Taxonomic heterogeneity of strains comprising Gluconacetobacter hansenii. J. Gen. Appl. Microbiol. 45, 295-300.

[17] Boesch, C. (1994) Vergleich von spezifischen DNA-Sequenzen in der Taxonomie von Essigsäurebakterien. Graduation Thesis, Institute of Food Science and Technology, ETH, Zürich.

[18] Bernardo, E.B., Neilan, B.A. and Couperwhite, I. (1998) Characterization, differentiation and identification of wild-type cellulose-synthesizing Acetobacter strains involved in Nata de Coco production. Syst. Appl. Microbiol. 21, 599-608.

[19] Trček, J. and Raspor, P. (1999) Molecular characterization of acetic acid bacteria isolated from spirit vinegar. Food Technol. Biotechnol. 37, 113-116.

[20] Fuentes-Ramírez, L.E., Bustillos-Cristales, R., Tapia-Hernández, A., Jiménez-Salgado, T., Wang, E.T., Martínez-Romero, E. and Caballero-Mellado, J. (2001) Novel nitrogen-fixing acetic acid bacteria, Gluconacetobacter johannae sp. nov. and Gluconacetobacter azotocaptans sp. nov., associated with coffee plants. Int. J. Syst. Evol. Microbiol. 51, 1305-1314.

[21] Katsura, K., Kawasaki, H., Potacharoen, W., Saono, S., Seki, T., Yamada, Y., Uchimura, T. and Komagata, K. (2001) Asaia siamensis sp. nov., an acetic acid bacterium in the $\alpha$-Proteobacteria. Int. J. Syst. Evol. Microbiol. 51, 559-563.

[22] Lisdiyanti, P., Kawasaki, H., Seki, T., Yamada, Y., Uchimura, T. and Komagata, K. (2000) Systematic study of the genus Acetobacter with description of Acetobacter indonesiensis sp. nov., Acetobacter tropicalis sp. nov., Acetobacter orleanensis (Henneberg 1906) comb. nov., Acetobacter lovaniensis (Frateur 1950) comb. nov., and Acetobacter estunensis (Carr 1985) comb. nov.. J. Gen. Appl. Microbiol. $46,147-165$.

[23] Schüller, G., Hertel, C. and Hammes, W.P. (2000) Gluconacetobacter entanii sp. nov., isolated from submerged high-acid industrial vinegar fermentations. Int. J. Syst. Evol. Microbiol. 50, 2013-2020.

[24] Sokollek, S.J., Hertel, C. and Hammes, W.P. (1998) Description of Acetobacter oboediens sp. nov. and Acetobacter pomorum sp. nov., two new species isolated from industrial vinegar fermentations. Int. J. Syst. Bacteriol. 48, 935-940.

[25] Trček, J., Raspor, P. and Teuber, M. (2000) Molecular identification of Acetobacter isolates from submerged vinegar production, sequence analysis of plasmid pJK2-1 and application in development of a cloning vector. Appl. Microbiol. Biotechnol. 53, 289-295.

[26] Franke, I.H., Fegan, M., Hayward, C., Leonard, G., Stackebrandt, E. and Lindsay, I.S. (1999) Description of Gluconacetobacter sacchari sp. nov., a new species of acetic acid bacterium isolated from the leaf sheath of sugar cane and from the pink sugar-cane mealy bug. Int. J. Syst. Bacteriol. 49, 1681-1693.

[27] Lane, D.J. (1991) 16S/23S rRNA sequencing. In: Nucleic Acid Techniques in Bacterial Systematics (Stackebrandt, E. and Goodfellow, M., Eds.), pp. 115-175. Wiley, Chichester.

[28] Brosius, J., Dull, T.J., Sleeter, D.D. and Noller, H.F. (1981) Gene organization and primary structure of a ribosomal RNA operon from Escherichia coli. J. Mol. Biol. 148, 107-127. 